\title{
Cytogenetical Studies in the Genus Cymbopogon Spreng II. Meiotic studies in six species and their varieties
}

\author{
Vijeshwar Verma and S.N. Sobti \\ Regional Research Laboratory, Jammu Tawi, India
}

Accepted January 18, 1984

The genus Cymbopogon includes some economically very important aromatic grasses. The members of this genus are quite common in tropical and sub-tropical part of the eastern hemisphere. About 20 species are reported in India which are distributed in the regions having abundant rainfall (Bor 1953, 1960, Jagdish Chandra 1975, Verma 1981). Most of the species belonging to this genus show morphological diversity indicating the possibility due to gene exchange between the species.

In order to understand the basis of diversity and variability a detailed study of morphology, breeding system, karyotype and pairing behaviour of the chromosomes in the meiosis of six Indian species and their varieties was undertaken. Detailed karyological studies of the above species/varieties were reported earlier (Verma and Sobti 1982). The present study deals with the aspects of morphology and male meiosis in the above species and varieties of genus Cymbopogon

\section{Material and methods}

The species and varieties investigated alongwith their chromosome numbers and places of collection are given in Table 1. The above plants were collected from different places in India and are maintained in the experimental garden of RRL, Jammu. Observations on morphological characteristics of the plants were made in the field based on 5-10 plants in each species. To provide a visual impression of comparison of species, polygraphs were prepared with the help of twelve important characters (Fig. I).

For meiotic preparation squash method using aceto-carmine was followed. The slides were analysed invariably before making them permanent and photographs were taken also at the same time. Later the slides were made permanent by the usual method using DPX as the mountant (Darlington and La Cour 1958).

\section{Results}

The six species of Cymbopogon alongwith their varieties included in the present investigation are well known, but detailed description with measurements of important diagnostic organs was lacking. Fig. 1 shows the comparative morphology of the species and varieties in the form of polygraphs.

Out of the nine varieties of six Cymbopogon species examined 5 were diploids 
with $2 n=20,2$ tetraploids with $2 n=40$ and 2 hexaploids with $2 n=60$. Detailed karyotypic studies of these plants were reported earlier (Verma and Sobti 1982).

The meiosis is normal in all the eight species and varieties investigated (Cytotype II of C. flexuosus, $(2 \mathrm{n}=40)$ included in the karyotypic study could not be studied for its meiosis as it did not flower). The average chromosome association at diakinesis-metaphase I and chiasma frequency per PMC and per bivalent (including multivalents, if any) are given in the Table 2 , in each species.

Table 1. Place of collection and $2 \mathrm{n}$ chromosome number of the species and varieties of Cymbopogon

\begin{tabular}{|c|c|c|c|}
\hline & Name of the species & $\begin{array}{l}\text { Chromosome } \\
\text { number }(2 n)\end{array}$ & Place of collection \\
\hline 1 & C. jwaranousa (Jones) Schult & 20 & $\begin{array}{l}\text { Srinagar, Saharanpur, Agra and } \\
\text { Nainital }\end{array}$ \\
\hline 2 & $\begin{array}{l}\text { C. flexuosus (Nees ex. Steud) Wats. } \\
\text { (genaniol chemotype) }\end{array}$ & 20 & $\begin{array}{l}\text { South and South Eastern Regions } \\
\text { (Coonoor, Coimbatore, Cochin and } \\
\text { Travancore) }\end{array}$ \\
\hline 3 & $\begin{array}{l}\text { C. flexuosus (Nees ex. Steud.) Wats. } \\
\text { (citral chemotype) }\end{array}$ & 20 & - do - \\
\hline 4 & C. martinit var. motia (Roxb.) Wats. & 20 & Baroda, Amroati, Nagpur, Dehra Dun \\
\hline 5 & C. martinii var. sofia (Roxb.) Wats. & 40 & Kudh (in J \& K), Dalhausie, Mussorie \\
\hline 6 & C. nardus var. confertiflorus Stapf. ex Bor. & 20 & $\begin{array}{l}\text { South and South Eastern Regions } \\
\text { (Coonoor, Kodaikanal, Pulneys, } \\
\text { Palghat and Nandi Hills). }\end{array}$ \\
\hline 7 & C. khasianus (Hack.) Stapf ex Bor. & 60 & $\begin{array}{l}\text { North Eastern Regions (Khasihills, } \\
\text { Arunachal Pradesh) }\end{array}$ \\
\hline 8 & C. pendulus (Nees. ex Steud.) Wats. & 60 & $\begin{array}{l}\text { Sub-Himalayan Regions (Darjeeling, } \\
\text { Khasi Hills, Garo Hills and Manipur) }\end{array}$ \\
\hline
\end{tabular}

Fig. II shows the microphotographs of different stages in the male meiosis in the different species and varieties of Cymbopogon. Among the diploid species $(2 \mathrm{n}=20)$ only C. flexuosus (citral type) exhibited quadrivalent formation (Fig. II-6), while all other species (C. nardus var. confertiflorus, C. flexuosus (geraniol type), C. Jawarancusa and $C$. martinii var. motia) had fairly regular chromosome pairing with mostly bivalent associations (Figs. II. 1-5). However, in some of PMCs the small chromosomes showed precocious chiasma separation resulting in univalent formation.

The plants belonging to tetraploid species, C. martinii var. sofia, exhibited peculiar meiosis. About $5 \%$ of the PMCs (3 out of 60 cells studied) exhibited loose hexavalent formation (Fig. II-9) and $51.6 \%$ of the PMCs had at least one quadrivalent (Table 2). The rest of the cells showed normal 20 bivalent formation at diakinesis-metaphase I stages (Fig. II-7).

Plants belonging to the two hexaploid species (C. pendulus and C. khasianus, $2 \mathrm{n}=60$ ) showed normal 30 bivalents formation in most of its PMCs (Figs. III, 10 and 11). However, quadrivalent formation was observed in $37.1 \%$ PMCs of $C$. pendulus and $20 \%$ PMCs of C. khasianus, respectively (Fig. III-12). Neither of the species exhibited any hexavalent or any other multivalent formation at diakinesis- 

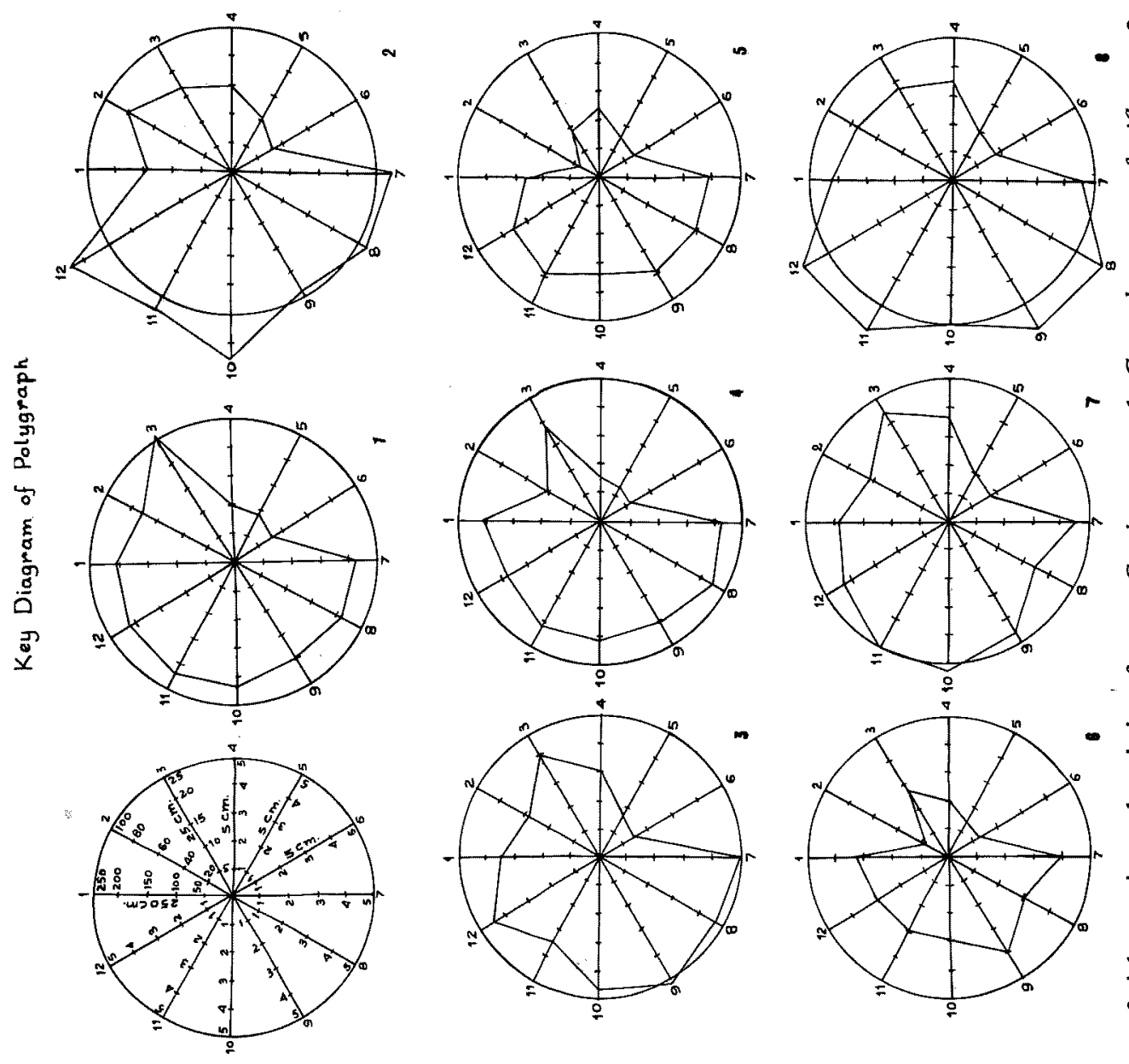

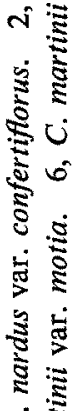
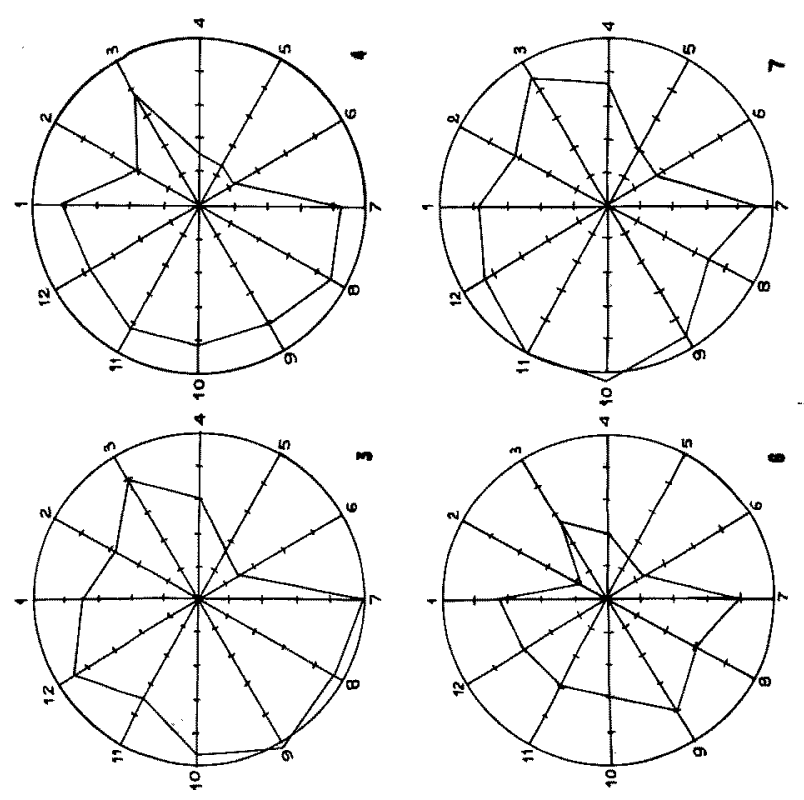

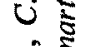

$-2$

宊

它 $\dot{8} \cdot \frac{5}{3}$

合变

$\circlearrowleft \div 0$

色 $\infty$

0

40

.

造证

$\because \sigma^{\circ}$

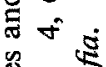

$\cdot \frac{\mathscr{S}}{8} \dot{8}$

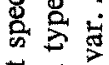

曾

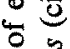

过

丰

$\dot{0}$

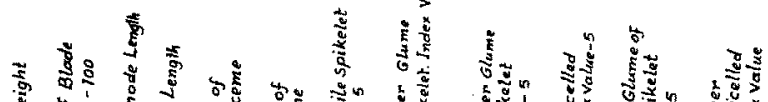

둥

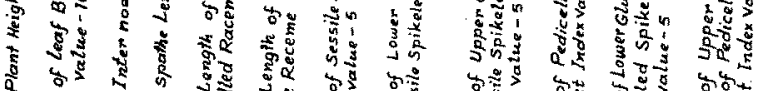

Q कर

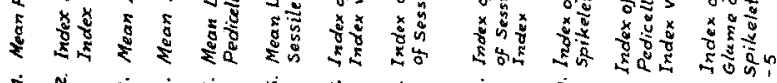

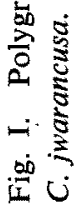


metaphase I stages.

Anaphases and telophases in all the above species of Cymbopogon were fairly normal showing equal distribution of chromosomes to the two poles except for $20-25 \%$ of the PMCs in tetraploid species, C. martinii var. sofia, which showed varying numbers of dividing and non-dividing laggards (Fig. III-13).
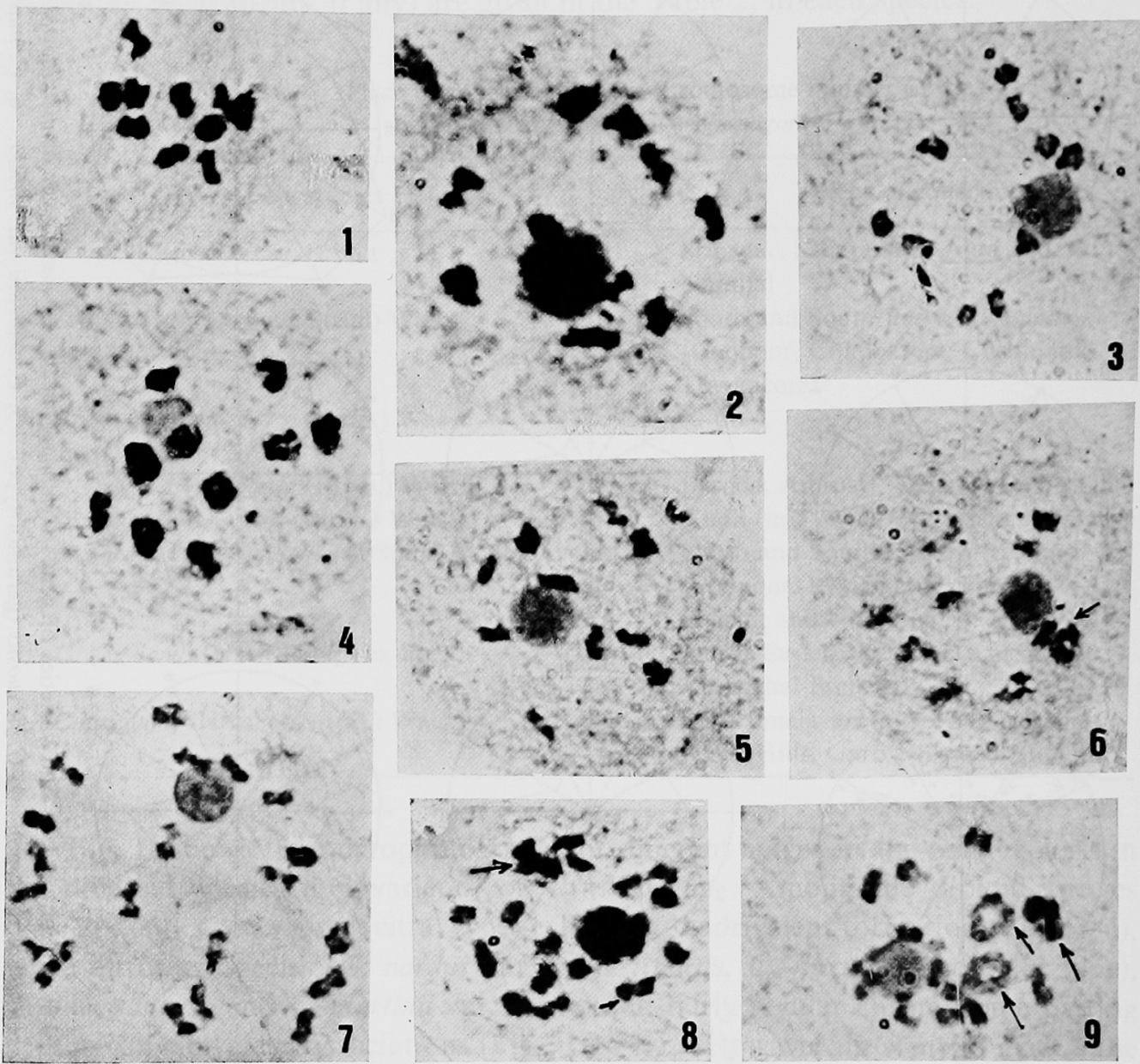

3

Figs. II. Microphotographs of male meiotic stages in 8 species and varieties of Cymbopogon. 1, diakinesis in $C$. nardus var. confertiflorus, $2 \mathrm{n}=20=10 \mathrm{II}$. 2, diakinesis in $C$. flexuosus (geraniol type) $2 n=20=10$ II. 3, diakinesis in C. jwarancusa, $2 n=20=10$ II. 4, diakinesis in C. martinii var. motia, $2 \mathrm{n}=20=10 \mathrm{II}$. 5, diakinesis in C. flexuosus (citral type) $2 \mathrm{n}=20=10 \mathrm{II}$. 6, diakinesis in C. flexuosus (citral type) $2 \mathrm{n}=20=1 \mathrm{IV}+8 \mathrm{II}$. 7, diakinesis in C. martinii var. sofia, $2 \mathrm{n}=40=20$ II. 8, diakinesis in C. martinii var. sofia, $2 \mathrm{n}=40=3 \mathrm{IV}+14 \mathrm{II}$. 9, diakinesis in $C$. martinii var. sofia, $2 \mathrm{n}=40=1 \mathrm{VI}+1 \mathrm{IV}+15 \mathrm{II}$.

Pollen fertility varied with the weather conditions in all the 8 species and varieties included in the present study. Most of the plants had good fertility in the months October-November and later it reduced sharply probably due to fall in temperature in the winter months. There was marginal improvement of fertility again in the months of March-April. However, the meiosis remained normal 
without much effect of cold temperatures in most of the species, except in C. nardus var. confertiflorus and $C$. jwaranousa where in formation of a few polynucleate PMCs were recorded in the peak winter months.

Table 2. Mean chromosome pairing and chiasma frequencies of PMCs and bivalents at diakinesis in Cymbopogon species

\begin{tabular}{|c|c|c|c|c|c|c|c|c|}
\hline \multirow{2}{*}{$\begin{array}{l}\text { Cymbopogon } \\
\text { species }\end{array}$} & \multirow{2}{*}{$\begin{array}{l}\text { Chr. } \\
\text { no. } \\
\text { (2n) }\end{array}$} & \multicolumn{5}{|c|}{ Mean chromosome pairing per cell } & \multicolumn{2}{|c|}{$\begin{array}{r}\text { Mean chiasma } \\
\text { frequency }\end{array}$} \\
\hline & & I & II & III & IV & VI & $\begin{array}{l}\text { per } \\
\text { PMC }\end{array}$ & $\begin{array}{c}\text { per } \\
\text { bivalent }\end{array}$ \\
\hline $\begin{array}{l}\text { C. nardus var. } \\
\text { confertiflorus }\end{array}$ & 20 & 0.28 & 9.86 & - & - & - & 21.31 & 2.12 \\
\hline $\begin{array}{l}\text { C. flexuosus } \\
\text { (geraniol chemotype) }\end{array}$ & 20 & 0.06 & 9.97 & - & - & - & 21.89 & 2.19 \\
\hline $\begin{array}{l}\text { C. flexuosus } \\
\text { (citral chemotype) }\end{array}$ & 20 & 0.74 & 9.11 & - & 0.26 & - & 22.68 & 2.23 \\
\hline C. jawarancusa & 20 & 0.07 & 9.97 & - & - & - & 21.5 & 2.12 \\
\hline C. martinii var. motia & 20 & 0.1 & 9.95 & - & - & - & 20.4 & 1.91 \\
\hline C. martinii var. sofia & 40 & 0.63 & 17.80 & - & 0.87 & 0.05 & 45.9 & 2.33 \\
\hline C. pendulus & 60 & - & 29.03 & - & 0.49 & - & 61.83 & 2.06 \\
\hline C. khasianus & 60 & 0.27 & 29.29 & - & 0.29 & - & 60.00 & 2.01 \\
\hline
\end{tabular}

\section{Discussion}

The genus Cymbopogon includes species which, based upon base number $\mathrm{x}=10$ chromosomes, are diploids, tetraploids and hexaploids. This base number $\mathrm{x}=10$ is also the basic number of many other genera of the tribe Andropogoneae (Avdulov 1931) to which this genus belongs. However, Mehra and Sharma (1975) suggested the base number $\mathrm{x}=5$ for the tribe Andropogoneae as a whole supporting the earlier reports of Celarier (1956) and Mehra et al. (1968). According to these authors the base number $\mathrm{x}=5$ being unstable duplicated earlier in the evolutionary history of the tribe. The diploids with $2 \mathrm{n}=20$ chromosomes include $C$. nardus var. confertiflorus, C. flexuosus (geraniol and citral chemotypes), C. jwarancusa and C. martinii var. motia. The earlier records of chromosome number (Table 1) were also the same except for $C$. martinii var. motia in which conflicting reports were made by Mehra and Sharma (1975). The presence of ten bivalents in most of the PMCs of all the diploids at diakinesis-metaphase-I stages and normal segregation at anaphase I and II stages shows that they have fairly regular meiosis except in those PMCs which have accessory chromosomes (Table 2). The accessory chromosomes were recorded only in three of the diploids with total absence in tetraploids and hexaploids (to be published elsewhere).

Like diploids the hexaploids $C$. pendulus and $C$. khasianus also showed normal regular meiosis by forming 30 bivalents in 60 to $67 \%$ of the PMCs studied in both the species. The presence of 0 to 3 quadrivalents in some cells $(20 \%$ and $37 \%$ PMCs in two species, respectively) probably represents chromosomal rearrangements. The karyological studies (Verma and Sobti 1982) support the near complete homology of the chromosomes. 
However, the meiosis in the tetraploid species C. martinii var. sofia $(2 n=40)$ is peculiar in the sense that 20 bivalents formation was noticed only in $43.4 \%$ of PMCs while 51.6\% PMCs had at least one quadrivalent and 5\% PMCs hexavalent formation. The multivalent formation probably represents chromosomal rearrangements (translocations and inversions). But on the whole the meiosis in this species remains to be normal. Formation of multivalents in some populations of this species and also in C. coloratus has also been reported by other workers (Narayan and Jagadish Chandra 1966, Jagadish Chandra and Narayan 1971). This suggests that this species is probably a segmental polyploid.

Muller (1925) attributed the presence of polyploidy, more commonly in plants

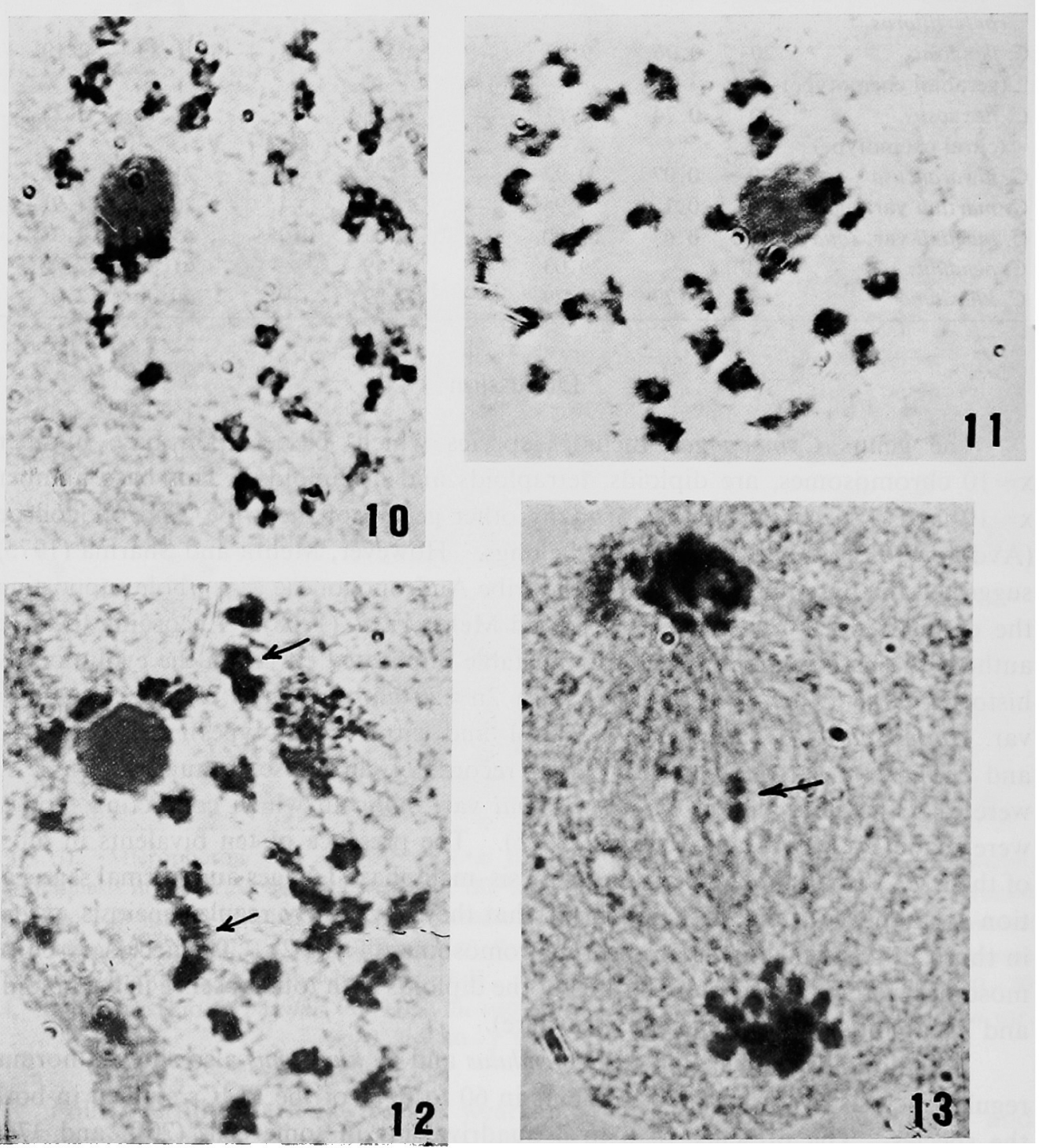

Figs. III. Microphotographs of male meiotic stages in 8 species and varieties of Cymbopogon. 10, diakinesis in C. pendulus, $2 \mathrm{n}=60=30 \mathrm{II}$. 11, diakinesis in C. khasianus, $2 \mathrm{n}=60=30 \mathrm{II}$. 12, diakinesis in $C$. khasianus, $2 \mathrm{n}=60=2 \mathrm{IV}+26 \mathrm{II}$. 13, anaphase I in $C$. martinii var. sofia showing a dividing laggard. 
and less commonly in animals, to absence of sex chromosomes in plants. Muller's hypothesis is partly confirmed as in animals and partly un-confirmed as in some dioecious plant groups where polyploidy is present (Grant 1971). Even in plants polyploidy is not universally present, rather it is present in some families, genera or species groups and absent in others. The distribution of polyploidy in the plant kingdom indicates that the origin of polyploidy is controlled by a set of factors, thus the mechanism is complex and it is not as simple as explained by Muller (1925). Grant (1971) recognises three sets of primary factors and some secondary factors which promote polyploidy.

The first of these factors is the existence of diploid species carrying different genomes and subgenomes. The second is natural hybridisation between these species and the third is a long lived perennial growth habit to increase the chances of somatic doubling; or, as a partial compensation in short lived annuals an autogamous breeding system, to increase the chances of union of un-reduced gametes. According to Grant, if any of these conditions is lacking in any given plant group, polyploidy in that group is either absent or rare.

As mentioned by Grant (1971) polyploidy usually takes place after hybridisation between related species whose genomes either have differentiated fully or partly. Such hybrids after chromosome doubling give rise to either allopolyploid or segmental allopolyploidy. Autopolyploids, however, are formed through somatic doubling. But we donot know whether the rarity of autopolyploids in nature is owing to its actual rare occurrence or mostly those autopolyploids survive which develop a mechanism such as gene controlled pairing, to suppress multivalent formation. Such an autopolyploid would look cytologically like a segmental allopolyploid or even an allopolyploid. The same would be true in segmental allopolyploid as seen in genera Triticum (Kimer and Riley 1963), Bothriochloa, Capillipedium and Dichanthium (Chheda and Harlan 1962, Faruqi 1964). Under these conditions natural selection in autopolyploids and segmental allopolyploids would favour such chromosomal changes which eventually result in the reduction of multivalents and consequently it would increase the fertility of the organism. Since gene controlled pairing suppresses multivalent formation in a single step, it would be of significant importance in the promotion of polyploidy, where the two genomes are either similar or only partly differentiated.

Cytological abnormalities like cytomixis, formation of syncytes and giant pollens, polyploid drop and other meiotic anomalies, have been recorded in quite a few species of Cymbopogon (Jagadish Chandra 1969, 1970, Sudarshan and Jagadish Chandra 1980, 1981, Subrahmanya and Jagadish Chandra 1980). The species studied above more or less exhibited normal meiosis without any of the above abnormalities except in $C$. nardus var. confertiflorus and $C$. jwaranousa which showed the formation of occasional polynucleate PMCs in the months of peak winter i.e. December and January. This probably is a mere low temperature effect.

\section{Summary}

Meiotic studies in six Indian Cymbopogon species and their varieties/chemo- 
types were made from pollen mother cells. The investigated taxa included 5 diploids $(2 n=20)$, one tetraploid $(2 n=40)$ and two hexaploids $(2 n=60)$. Both diploids as well as hexaploids exhibited fairly normal meiosis with ten and thirty bivalents formation, respectively. However, the tetraploid species ( $C$. martinii var. sofia, $2 \mathrm{n}=40$ ) showed peculiar meiosis by forming multivalent configurations like quadrivalents and hexavalents, suggesting a segmental polyploid nature.

\section{Acknowledgements}

The authors are highly thankful to Dr. C. K. Atal, Director, Regional Research Laboratory, Jammu for providing the fecilities. The authors are also thankful to Mr. R. P. Sharma for meticulous typing.

\section{References}

Avdulov, M. P. 1931. Karyosystematische Untersuchungen der Familie Gramineen. Bull. Appl. Bot. P. 1 Breed. Suppl. 44: 428.

Babu C. N. 1936. Chromosome numbers in Cymbopogon species. Curr. Sci. 4: 739, 874-875.

Baquar, S. R. and Saced, M. 1969. Chromosome studies and polyploidy analysis in grasses of West Pakistan. I. Caryologia 22: 103-111.

Bor, N. L. 1953. The genus Cymbopogon in India, Burma and Ceylon. Part I. J. Bombay Nat. Hist. Soc. 51 : 890-916.

- 1960. The Grasses of Burma, Ceylon, India and Pakistan. pp. 121-132. Pergamon Press, New York.

Celarier, R. P. 1956. Additional evidence for five as the basic number of the Andropogoneae. Rhodora 58: 135-143.

Chheda, H. R. and Harlan, J. R. 1962. Mode of chromosome association in Bothriochloa hybrids. Caryologia 15: 461-476.

Darlington, C. D. and La Cour, L. F. 1958. Handling of Chromosomes. Allen and Unwin, London.

Faruqi, S. A. 1964. Cytogenetical studies of the Bothriochloa intermedia complex. Cytologia 29: 280-297.

Grant, V. 1971. Plant Speciation. Columbia Univ. Press. New York.

Gupta, B. K. 1965. Chromosome number in some species of Cymbopogon. Proc. Ind. Acad. Sci. 62B (3): 155-157.

- 1969. Studies in the genus Cymbopogon Spreng. I. Chromosome studies in Indian Cymbopogons. Proc. Ind. Acad. Sci. 70B (2): 80-87.

Jagadish Chandra, K. S. 1969. Cytomixis in triploid species of Cymbopogon (Gramineae). Proc. 56th Indian Sci. Congr. Part III. p. 357. Indian Sci. Congr. Assn. Calcutta.

- 1970. Polyploid drop or degenerating chromosomes in Cymbopogon martinii. Proc. 57th Indian Sci. Congr. Part II. p. 286. Indian Sci. Congr. Assn. Calcutta.

- 1975, Recent studies on Cymbopogon Spreng. (Aromatic grasses) with special reference to Indian taxa: Cultivation and ecology: A review. J. Plantation Crops 3 (1): 1-5.

- and Narayan, K. N. 1971. Studies on the supernumerary chromosomes in the genus Cymbopogon. (Poaceae). First All India Cong. of Cytology Abs. 1-86.

Kimber, G. and Riley, R. 1963. The relationship of the diploid progenitor of hexaploid wheat. Canad. J. Genet. Cytol. 5: 83-88.

Mehra, P. N., Khosla, P. K., Kohli, B. L. and Koonar J. S. 1968. Cytological studies in the North Indian grasses (Part I). Res. Bull. Punjab Univ. 19: 157-230.

- and Remanandan, P. 1973. Cytological investigation on West Himalayan Panicoideae. Cytologia 38: 259-270. 
— and Sharma, M. L. 1975. Cytogenetical studies in some Centra and Eastern Himalayan grasses. I. The Andropogoneae. Cytologia 40: 61-74.

Mitra, K. and Datta, N. 1967. In IOPB chromosome number reports. XIII. Taxon 169: 445461.

Muller, H. J. 1925. Why polyploidy is rarer in animals than in plants. Amer. Nat. 59: 346-353.

Narayan, K. N. and Jagadish Chandra, K.S. 1966. Cytological studies in species of Cymbopogon from South India. Sci. J. Mysore Univ. 20 (1 and 2): 66-72.

Raghavan, R. and Arora, M. C. 1958. Chromosome numbers in Indian medicinal plants. II. Proc. Ind. Acad. Sci. B47: 352-358.

Sobti, S. N., Verma, V., Rao, B. L. and Pushpangadan, P. 1979, In IOPB chromosome number reports. LXV. Taxon 28 (4): 627-637.

Subramanya, B. S. and Jagadish Chandra, K. S. 1980. The diffuse stage during the meiotic prophase in the hexaploid lemongrass. Curr. Sci. $49(18): 712-713$.

Sudershan, M. R. and Jagadish Chandra, K. S. 1980, The diffuse stage in the meiosis of PMCs of Cymbopogon caesius. Cur. Sci. 49 (7): 286-287.

- and - 1981, Unusual meiotic behaviour and formation of $2 \mathrm{n}$ pollen in tetraploid Cymbopogon caesius (Nees) Stapf (Poaceae). Cytologia 46: 117-123.

Verma, V. 1981. Cytogenetical and hybridisation studies in the genus Cymbopogon Spreng. Ph. D. Thesis submitted to the Univ. of Jammu, Jammu.

- and Sobti, S. N. 1982. Cytogenetical studies in the genus Cymbopogon Spreng. I. Karyological studies in six species and their varieties. The Nucleus 25 (3): 165-171. 